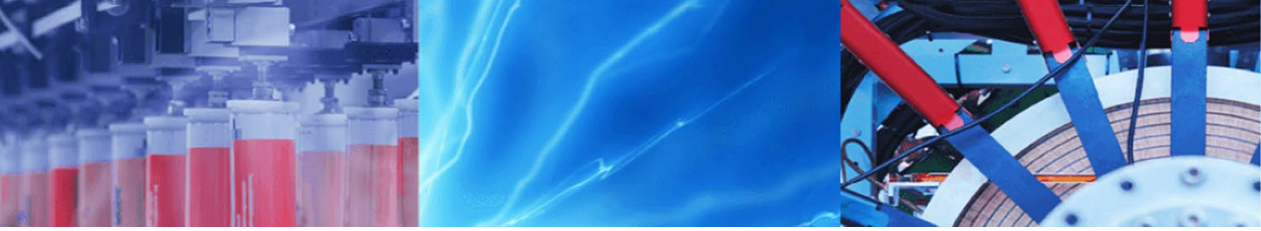

Research Article

\title{
Antibacterial activity of water soluble dye capped zinc oxide nanoparticles synthesised from waste $\mathrm{Zn}-\mathrm{C}$ battery
}

\author{
M. Giridhar ${ }^{2}$ - H. S. Bhojya Naik ${ }^{1}$ - C. N. Sudhamani ${ }^{1} \cdot$ R. Viswanath ${ }^{1} \cdot$ R. Kenchappa $^{1} \cdot$ Sameer Patil $^{3}$
}

(c) Springer Nature Switzerland AG 2019

\begin{abstract}
Antibacterial activity of functionalized $\mathrm{ZnO}$ nanoparticles synthesized from waste $\mathrm{Zn}-\mathrm{C}$ battery by microwave method was investigated, water soluble 1-(carboxymethyl)-4-[(E)-2-(3-methoxy-4-methylphenyl)ethenyl] pyridin-1-ium photosensitizer was used as capping agent to control the size of nanoparticle. The characterization of the samples was done with the help of UV-visible spectroscopy, FTIR, SEM-EDS and XRD. The nanoparticles have hexagonal wurtzite structure with a mean diameter of $19.7 \mathrm{~nm}$ for $3 \%$ dye capped nanoparticle and $30.6 \mathrm{~nm}$ for uncapped nanoparticle and are composed by a mixture of small crystallites and disordered $\mathrm{ZnO}$ particles. Capped $\mathrm{ZnO}$ nanoparticles showed high antibacterial (tested on E. coli and B. subtilis) activities compared to that of uncapped nanoparticles under the same experimental conditions. This novel water soluble dye capped $\mathrm{ZnO}$ nanoparticles emerged as excellent antibacterial agent, the results show minimum inhibitory concentration of 0.39 and $1.56 \mathrm{for} B$. subtilis and E. coli and highest zone of inhibition was at concentration of $5 \mathrm{mg} / \mathrm{ml}$. The bioactivity showed dye capped nanoparticle to be new class of antibacterial agent.
\end{abstract}

Keywords 4-Styrylpyridine $\cdot$ ZnO Nanoparticles $\cdot$ Capping agent $\cdot$ Antibacterial activity $\cdot$ B. subtilis $\cdot$ E. coli

\section{Introduction}

In recent years bio-inspired nanoparticles prepared by functionalization of small organic molecules is of increasing interest [1]. Functionalization of NPs allows their possible applications in many fields such as drug delivery, nanomedicine, biosensors, and bionanotechnology [2-4]. The antibacterial activity of nanoparticle depend on various factors such as Particle size of NPs, composition, surface modification, intrinsic properties, and the type of microorganism $[5,6]$. For a nanoparticle to be effective antibacterial agent the interaction between bacteria and the Nanoparticle plays important role, for effective interaction nanoparticle should be lyophillic in nature [7]. Inorganic metal oxide nanoparticles are excellent antibacterial agents, the major drawback is their lyophobic nature [8] and large band gap [9], surface modification approaches aim at improving surface-assisted antibacterial properties by making nanoparticles lyophillic which increases interaction between nanoparticle and bacteria, shifting the wavelength of absorption towards visible region or reducing band gap and by increasing the photoinduced activity of nanoparticles $[10,11]$. Organic-inorganic monohybrids functionalized with water soluble photosensitizers could lead to novel antibacterial agents for photoinduced antibacterial applications and lyophillic nature induced in nanoparticle could lead to increased antibacterial activity due to increased interaction between nanoparticle and bacteria [12].

Zinc Oxide is well known metal oxide photocatalyst having many applications such as water treatment process, food packaging materials, dye sensitized solar cells etc. $[13,14]$. When a $\mathrm{ZnO}$ photocatalyst is irradiated with UV light, it directly excites $\mathrm{ZnO}$ by promoting electron

$\triangle$ H. S. Bhojya Naik, hsb_naik@rediffmail.com | 'Department of PG Studies and Research in Industrial Chemistry, School of Chemical Sciences, Kuvempu University, Shankaraghatta 577451, India. ${ }^{2}$ Department of Post Graduate in Chemistry, Government Science College, Hassan, Karnataka, India. ${ }^{3}$ Department of PG Studies and Research in Biochemistry, Kuvempu University, Shankaraghatta 577451 , India.

SN Applied Sciences (2019) 1:297 | https://doi.org/10.1007/s42452-019-0272-3 
from valance bond to conduction band which produce electron-hole pairs and generate various active oxygen species, such as hydroxyl radicals, hydrogen peroxide, superoxide radical anions, etc. [15]. ZnO nanoparticles shows inhibitory effect on the growth of $E$. coli and B.subtilis strains which was confirmed by previous reports $[16,17]$. Hence $\mathrm{ZnO}$ nanoparticles can be considered as potent antibacterial compound, but not as much as the established compound such as ampicillin [18]. ZnO being cheap and eco-friendly, the antibacterial properties of $\mathrm{ZnO}$ nanoparticles can be further improved by surface modification approaches so that these nanoparticles can be used in various industrial and medical applications $[19,20]$, the emergence of drug resistance bacteria has instigated researchers to develop novel nanomaterials with antibacterial capacity [21]. Assessing the influence of nanoparticles on microorganisms requires interaction between the microorganisms and the nanoparticles. Bulk metal oxide nanoparticles tend to agglomerate in aqueous, $\mathrm{pH}$-neutral bacterial growth media containing ions and proteins. The aim of this study was to introduce lyophillic property on nanoparticle which stabilizes $\mathrm{ZnO}$ nanoparticles in LB medium in order to avoid agglomeration and increase nanoparticles and bacterial interaction.

Waste $\mathrm{Zn}-\mathrm{C}$ battery is an excellent alternative source of $\mathrm{Zinc}$, synthesis of $\mathrm{ZnO}$ nanoparticles from spent $\mathrm{Zn}-\mathrm{C}$ battery could provide commercially viable, environment friendly, ensure recyclability of spent $\mathrm{Zn}-\mathrm{C}$ batteries and sustainable benefits [22]. Many methods have been developed for synthesis such as sol-gel, hydrothermal, arc discharge, chemical vapour deposition, microbial route, oxidation process [23-25] etc., low temperature selective chemical precipitation is simple yet efficient technique for preparation of $\mathrm{ZnO}$ nanoparticles with organic capping agent $[26,27]$. Water soluble organic styrylpyridine photosensitizers was developed as capping agent, these organic photosensitizers has received much attention because of their electron injection properties, which is being exploited in dye sensitized solar cell applications [28], the charge on the capped nanoparticles provide stability and decreases agglomeration, and the water solubility of dye could increase lyophillic nature of nanoparticles and hence interaction between Bacteria and nanoparticle surface [29]. Organic photosensitizers are also being used in Photodynamic therapy which has emerged as novel method for the treatment of various infectious disease caused by bacteria, fungi, and viruses [30, 31]. In the present work we have synthesised 1-(carboxymethyl)-4-[(E)2-(3-methoxy-4-methylphenyl)ethenyl]pyridin-1-ium dye functionalized Zinc Oxide nanoparticles from waste $\mathrm{Zn}-\mathrm{C}$ battery by microwave method and evaluated the antibacterial activity of capped $\mathrm{ZnO}$ nanoparticles against $E$-Coli and $B$. subtilis bacteria. To our knowledge we have not seen the reports on synthesis of water soluble photosensitizer capped $\mathrm{ZnO}$ nanoparticles from spent $\mathrm{Zn}-\mathrm{C}$ battery by microwave method.

\section{Experimental}

\subsection{Materials and chemicals}

The Chemicals used for the preparation of target $\mathrm{ZnO}$ capped with dye 1-(carboxymethyl)-4-[(E)-2-(3-methoxy4-methylphenyl)ethenyl]pyridin-1-ium were 4-methyl pyridine, Chloroacetic acid, sodium hydroxide, vanillin, acetone and Ethanol. These chemicals were procured from Sigma Aldrich and were used in their pure from without any purification. A mixture of deionised water and methanol was used as solvent for fabrication of the targeted product.

\subsection{Synthesis}

The synthesis of dye 1-(carboxymethyl)-4-[(E)-2-(3-methoxy-4-methylphenyl)ethenyl]pyridin-1-ium is illustrated in Scheme 1, and was synthesised following the literature procedures [32].

\subsection{Synthesis of 1-carboxy-4-methylpyridin-1-ium}

A solution of 4-methylpyridine $(1.5 \mathrm{~g}, 16.1 \mathrm{mmol})$ and 1-chloroacetic acid $(1.52 \mathrm{~g}, 16.1 \mathrm{mmol})$ in ethyl acetate $(25 \mathrm{ml})$ was stirred for $2 \mathrm{~h}$ at room temperature $(303 \mathrm{~K})$. The resulting solid was filtered off and washed with ethylacetate to give (1), which was recrystallized from an aqueous ethanol ( $80 \%$

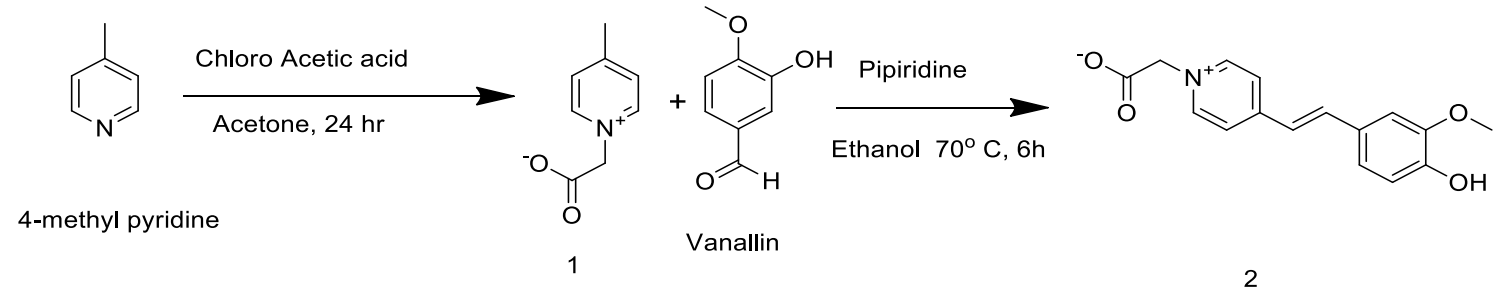

Scheme 1 Shows the synthesis route of 1-(carboxymethyl)-4-[(E)-2-(3-methoxy-4-methylphenyl)ethenyl]pyridin-1-ium 
v/v) solution ( $0.59 \mathrm{~g}, 1.78 \mathrm{~g}$ yield $73 \%) .{ }^{1} \mathrm{H}$ NMR $(500 \mathrm{MHz}$, $\left.\mathrm{CD}_{3} \mathrm{OD}\right): \delta 2.36(3 \mathrm{H}, \mathrm{s}), 4.84(2 \mathrm{H}, \mathrm{q}), 722(2 \mathrm{H}, \mathrm{d}), 8.98(2 \mathrm{H}, \mathrm{d})$.

\subsection{Synthesis \\ of 1-(carboxymethyl)-4-[(E)-2-(3-meth- oxy-4-methylphenyl)ethenyl] pyridin-1-ium}

1-carboxy-4-methylpyridin-1-ium (1.5 g, $9.91 \mathrm{mmol})$, Vanillin $(0.95 \mathrm{~g}, 9.91 \mathrm{mmol})$, and $15 \mathrm{~mL}$ ethylacetate was mixed. Five drops of piperidine was added to the mixture. Then the solution was refluxed at $70^{\circ} \mathrm{C}$ for $6 \mathrm{~h}$, cooled the reaction mass, a dark orange-yellow solid was formed and filtered. The solid was washed twice with ethanol. Yellow solid was collected (1.95 g, yield 86\%). $\left.1 \mathrm{H} \mathrm{NMR} \mathrm{(500} \mathrm{MHz,} \mathrm{CD}_{3} \mathrm{OD}\right): \delta 6.04(2 \mathrm{H}$, s), $9.01(2 \mathrm{H}, \mathrm{d}), 8.09(2 \mathrm{H}, \mathrm{d}), 6.95(2 \mathrm{H}, \mathrm{d}), 6.99(1 \mathrm{H}, \mathrm{d}), 7.1(1 \mathrm{H}$, d), $5.35(1 \mathrm{H}, \mathrm{s}), 3.83(3 \mathrm{H}, \mathrm{s}) . \mathrm{m} / \mathrm{z}=229.38$.

\subsection{Nanoparticle synthesis}

Nanoparticle was synthesised by microwave assisted sol-gel method from spent $\mathrm{Zn}-\mathrm{C}$ battery [33]. Waste $\mathrm{Zn}-\mathrm{C}$ battery was manually dismantled to obtain the powdered materials which is positive electrode and contains mainly manganese dioxide and zinc oxide. The powder materials wetted with electrolyte was used as raw material to synthesize $\mathrm{ZnO}$ nanoparticles. The obtained powdered material was dried in the oven at $90^{\circ} \mathrm{C}$ for $2 \mathrm{~h}$ to remove moisture and the weight of the dried powder was $6.5 \mathrm{~g}$. The dried powder was crushed in pestle and mortar to obtain fine powder which was suspended in neutral $\mathrm{pH}$ distilled water and stirred at $60^{\circ} \mathrm{C}$ for $30 \mathrm{~min}$ to remove $\mathrm{KOH}$ and $\mathrm{NH}_{4} \mathrm{Cl}$ which are the electrolytes of the battery, the powder was filtered, dried at $90^{\circ} \mathrm{C}$ for $2 \mathrm{~h}$ and the weight of the dried powder was $5.29 \mathrm{~g}$, a loss in the weight of $9.5 \% \mathrm{v}$ was observed. A quantitative analysis at this stage by SEM-EDX showed the $\mathrm{Zn}$ and $\mathrm{Mn}$ content of the sample to be $25.2 \%$ and $40.8 \%$ respectively.

Zinc oxide nanoparticles were prepared by leaching technique using $\mathrm{H}_{2} \mathrm{SO}_{4}$ as leaching agent, the reactions of leaching are as shown below

$$
\begin{aligned}
& \mathrm{ZnO}+\mathrm{H}_{2} \mathrm{SO}_{4} \rightarrow \mathrm{ZnSO}_{4}+\mathrm{H}_{2} \mathrm{O} \\
& \mathrm{Mn}_{2} \mathrm{O}_{3}+\mathrm{H}_{2} \mathrm{SO}_{4} \rightarrow \mathrm{MnSO}_{4}+\mathrm{MnO}_{2}+\mathrm{H}_{2} \mathrm{O} \\
& \mathrm{Mn}_{3} \mathrm{O}_{4}+2 \mathrm{H}_{2} \mathrm{SO}_{4} \rightarrow 2 \mathrm{MnSO}_{4}+\mathrm{MnO}_{2}+2 \mathrm{H}_{2} \mathrm{O}
\end{aligned}
$$

Ascorbic acid was used as reducing agent to reduce $\mathrm{Mn}$ (IV) to $\mathrm{Mn}$ (II), an excess of reducing agent was used in the reaction to achieve reaction, the balanced reaction of reduction is showed below

$9 \mathrm{MnO}_{2}+9 \mathrm{H}_{2} \mathrm{SO}_{4}+\mathrm{C}_{6} \mathrm{H}_{8} \mathrm{O}_{6} \rightarrow 9 \mathrm{MnSO}_{4}+6 \mathrm{CO}_{2}+13 \mathrm{H}_{2} \mathrm{O}$

$2 \mathrm{~g}$ of spent $\mathrm{Zn}-\mathrm{C}$ electrode powder was suspended in $15 \mathrm{ml}$ of $2 \mathrm{M}$ sulphuric acid and $5 \mathrm{ml}$ of $0.15 \mathrm{M}$ ascorbic acid, the suspension was heated on water bath $70-80^{\circ} \mathrm{C}$ for $1 \mathrm{~h}$. The resulting solution was filtered to remove carbon, selective precipitation was carried out using $2 \mathrm{M}$ $\mathrm{NaOH}$ solution, an initial $\mathrm{pH}$ of 14 was set where Zinc hydroxide dissolves as it forms $\left[\mathrm{Zn}\left(\mathrm{OH}_{4}\right)\right]^{2-}$ whereas manganese hydroxide remains as precipitate was removed by centrifugation at $5000 \mathrm{rpm}$. To the above solution $60 \mathrm{mg}$ (3\% weight of $\mathrm{Zn}-\mathrm{C}$ electrode powder) of water soluble dye was added as capping agent and acidified with dilute $\mathrm{H}_{2} \mathrm{SO}_{4}$ to $\mathrm{pH} 10$ to repreciptate zinc as $\mathrm{Zn}(\mathrm{OH})_{2}$. The precipitate was centrifuged at $5000 \mathrm{rpm}$, washed 3-4 times with water to remove uncapped dye. Finally obtained nanoparticle was vacuum dried at $60^{\circ} \mathrm{C}$ for $8 \mathrm{~h}$, similarly uncapped $\mathrm{ZnO}$ nanoparticle was synthesised following same procedure as above without using dye. The obtained nanoparticles were subjected for further characterization.

\subsection{Antibacterial studies}

The antimicrobial activity for pure $\mathrm{ZnO}$ and dye capped $\mathrm{ZnO}$ nanoparticles were performed, we have chosen 3\% dye capped $\mathrm{ZnO}$ nanoparticle sample at different concentrations because of its optical absorption in visible region, samples were tested against Escherichia coli (ATCC Number 25922) gram negative bacteria and Bacillus subtillis (ATCC Number 6633) gram positive bacteria obtained from National Collection of Industrial Microorganisms, NCL, Pune, India for the given studies.

\subsection{Determining zone of inhibition}

Initially, the stock cultures of bacteria were revived by inoculating in broth media and grown at $37^{\circ} \mathrm{C}$ for $18 \mathrm{~h}$. The agar plates of the media (Peptone-10 $\mathrm{g}, \mathrm{NaCl}-10 \mathrm{~g}$ and Yeast extract $5 \mathrm{~g}$, Agar $20 \mathrm{~g}$ in $1000 \mathrm{ml}$ of distilled water) were prepared and wells were made in the plate. Each plate was inoculated with $18 \mathrm{~h}$ old cultures $\left(100 \mu \mathrm{l}, 10^{8}\right.$ $\mathrm{cfu} / \mathrm{ml}$ ) and spread evenly on the plate using sterile cotton swab. After $20 \mathrm{~min}$, the wells were filled with of compound of different concentration $(0.0195$ to $10 \mathrm{mg} / \mathrm{ml})$. All the plates were incubated at $37^{\circ} \mathrm{C}$ for $24 \mathrm{~h}$ and the diameter of inhibition zone were noted.

\subsection{MIC assay of Nps}

Test organism Escherichia coli (ATCC Number 25922) gram negative bacteria and Bacillus Subtillis (ATCC Number 6633) gram positive bacteria were grown separately in a $50 \mathrm{ml}$ sterilized nutrient broth medium incubated at $37{ }^{\circ} \mathrm{C}$ for $14 \mathrm{~h}$. On the subsequent day, test organism cultures were transferred at the rate of $1 \%$ in $100 \mathrm{ml}$ nutrient broth. The initial concentration of $5 \mathrm{mg} / \mathrm{ml}$ nanoparticle in nutrient broth was diluted using double fold serial dilution, $5 \mathrm{ml}$ of 
above stock solution was diluted with $5 \mathrm{ml}$ of sterile nutrient broth to obtain $5 \mathrm{mg} / \mathrm{ml}$ concentration. The process was repeated several times to obtain 5 to $0.0195 \mathrm{mg} / \mathrm{ml}$ concentrations. To the above of the each medium containing different concentration of $\mathrm{ZnO} \mathrm{Nps}, 0.1 \mathrm{ml}$ of the standard bacterial cell suspension was added and incubated at $37^{\circ} \mathrm{C}$ for $24 \mathrm{~h}$. The growth of the inoculums in the broth was assessed by colony count method on solid agar plates and the lowest concentration of the $\mathrm{ZnO}$ Nps which inhibited the growth of the test bacteria was taken as the minimum inhibitory concentration (MIC).

\subsection{Bacterial growth curves}

Bacterial growth curves for functionalized nanoparticles were performed to observe the effect of variation of nanoparticles concentration on growth of bacterial strains of E. coli and B. subtilis. Bacterial inoculums were prepared in sterile physiological saline $\left(1.5 \times 10^{8}\right.$ bacterial cells $\left./ \mathrm{ml}\right)$ using $24 \mathrm{~h}$ fresh bacterial cultures. Each flask was prepared which contained $20 \mathrm{ml}$ of nutrient broth with $0 \mu \mathrm{g} /$ $\mathrm{ml}$ (control), $50 \mu \mathrm{g} / \mathrm{ml}, 200 \mu \mathrm{g} / \mathrm{ml}, 500 \mu \mathrm{g} / \mathrm{ml}$ and $1000 \mu \mathrm{g} /$ $\mathrm{ml}$ of capped $\mathrm{ZnO}$ nanoparticles, respectively. The flasks were inoculated with $100 \mu \mathrm{l}$ of the bacterial suspension of each strain and incubated at $37^{\circ} \mathrm{C}$ under continuous stirring of 150 r.p.m. for $12 \mathrm{~h}$. The Optical Density (OD) of the cultures at $600 \mathrm{~nm}$ was measured for every $2 \mathrm{~h}$ over a period of $16 \mathrm{~h}$ to monitor bacterial growth. The readings obtained were plotted and comparative studies were performed between uncapped $\mathrm{ZnO}$ and $3 \%$ dye capped $\mathrm{ZnO}$ nanoparticles.

\section{Results and Discussion}

\subsection{Characterisation of nanoparticles}

The $\mathrm{ZnO}$ Nps were synthesized by chemical precipitation and surface modification approach from spent $\mathrm{Zn}-\mathrm{C}$ battery. The UV-Vis absorption spectra of synthesised NPs were measured in the range of $200 \mathrm{~nm}$ to $800 \mathrm{~nm}$. We observed a absorption peak at $\sim 310 \mathrm{~nm}$ as shown in Fig. 1a, which corresponds to a band gap of $3.6 \mathrm{eV}$ and is consistent to the previous report [34]. The presence of dye on the surface of $\mathrm{ZnO}$ nanoparticles as capping agent was confirmed from FTIR spectroscopy. Multiple peaks corresponding to different functional groups is observed in the spectra. Dye alone showed a spectrum which consists of broad band at $3400 \mathrm{~cm}^{-1}$ due to stretching of $\mathrm{O}-\mathrm{H}$ group of $-\mathrm{COOH}$, the sharp absorption band of $\mathrm{C}=\mathrm{O}$ of $\mathrm{COOH}$ due to vibration occur at 1715 and $1695 \mathrm{~cm}^{-1}, \mathrm{C}-\mathrm{H}$ stretching was at $1495 \mathrm{~cm}^{-1}$, the peak at $1050 \mathrm{~cm}^{-1}$ was due to $\mathrm{C}-\mathrm{O}$ stretching of $\mathrm{COOH}$. The FTIR
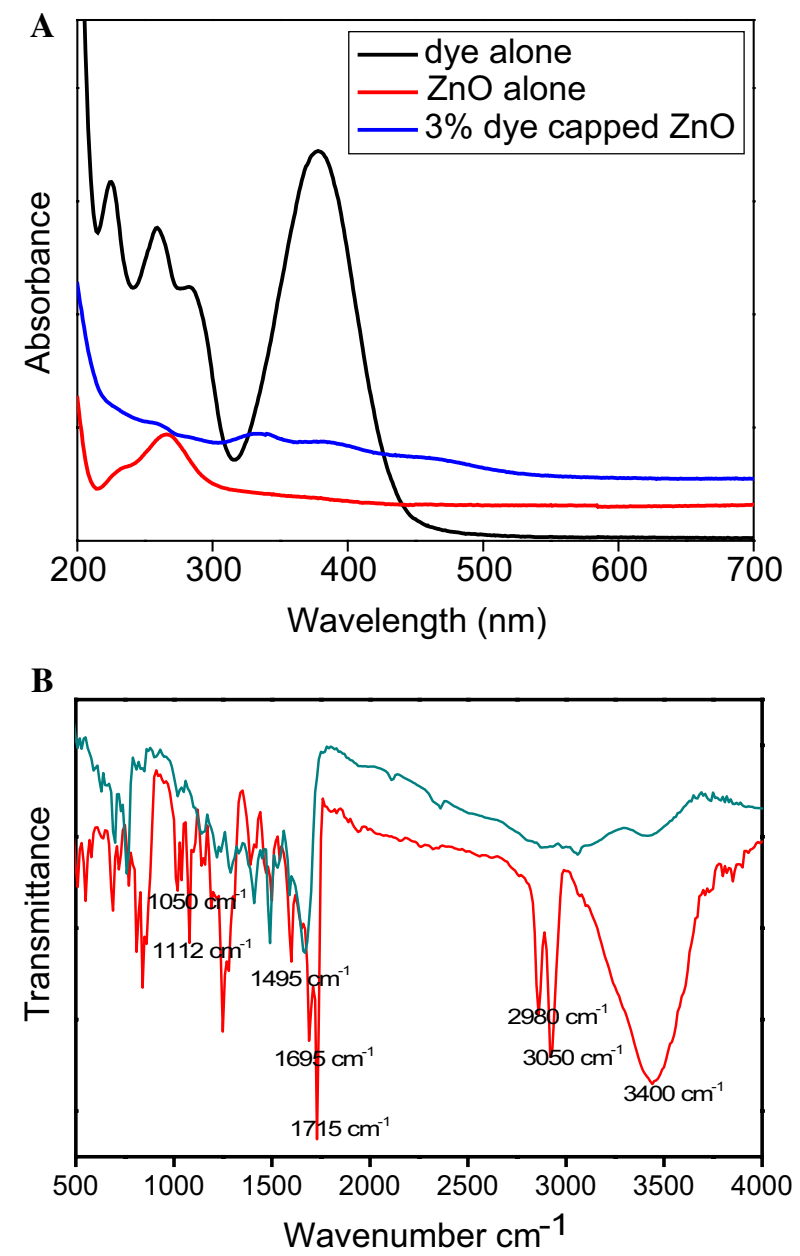

Fig. 1 a UV-Vis spectra of dye alone, uncapped $\mathrm{ZnO}$, and dye capped $\mathrm{ZnO}$ Nps synthesized by the precipitation and microwave method. b FTIR spectra of pure dye (Red) and 3\% dye capped $\mathrm{ZnO}$ Nps (Green)

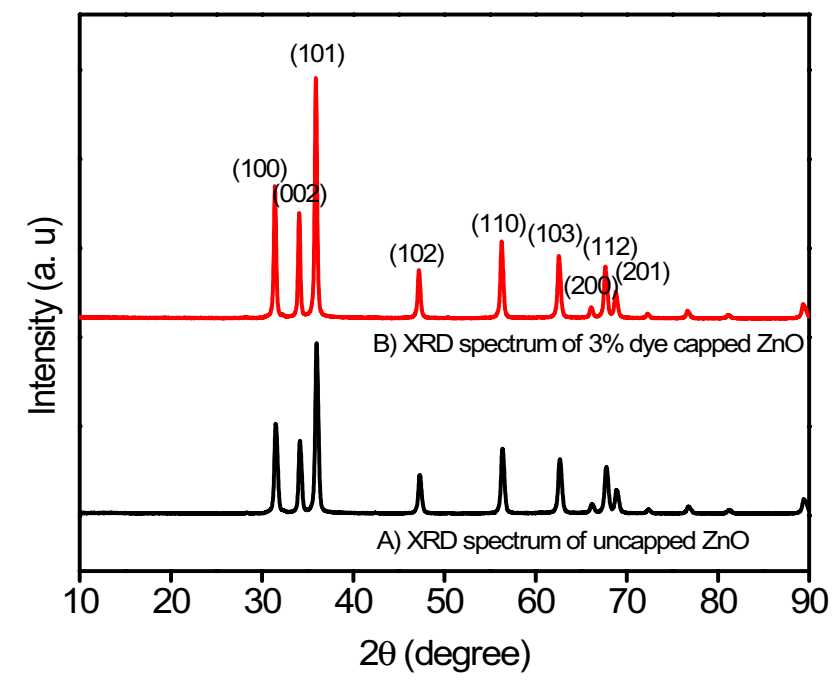

Fig. 2 (a) XRD pattern of uncapped ZnO Nps formed by precipitation and microwave method. (b) XRD pattern of 3\% dye capped $\mathrm{ZnO}$ Nps after surface modification 

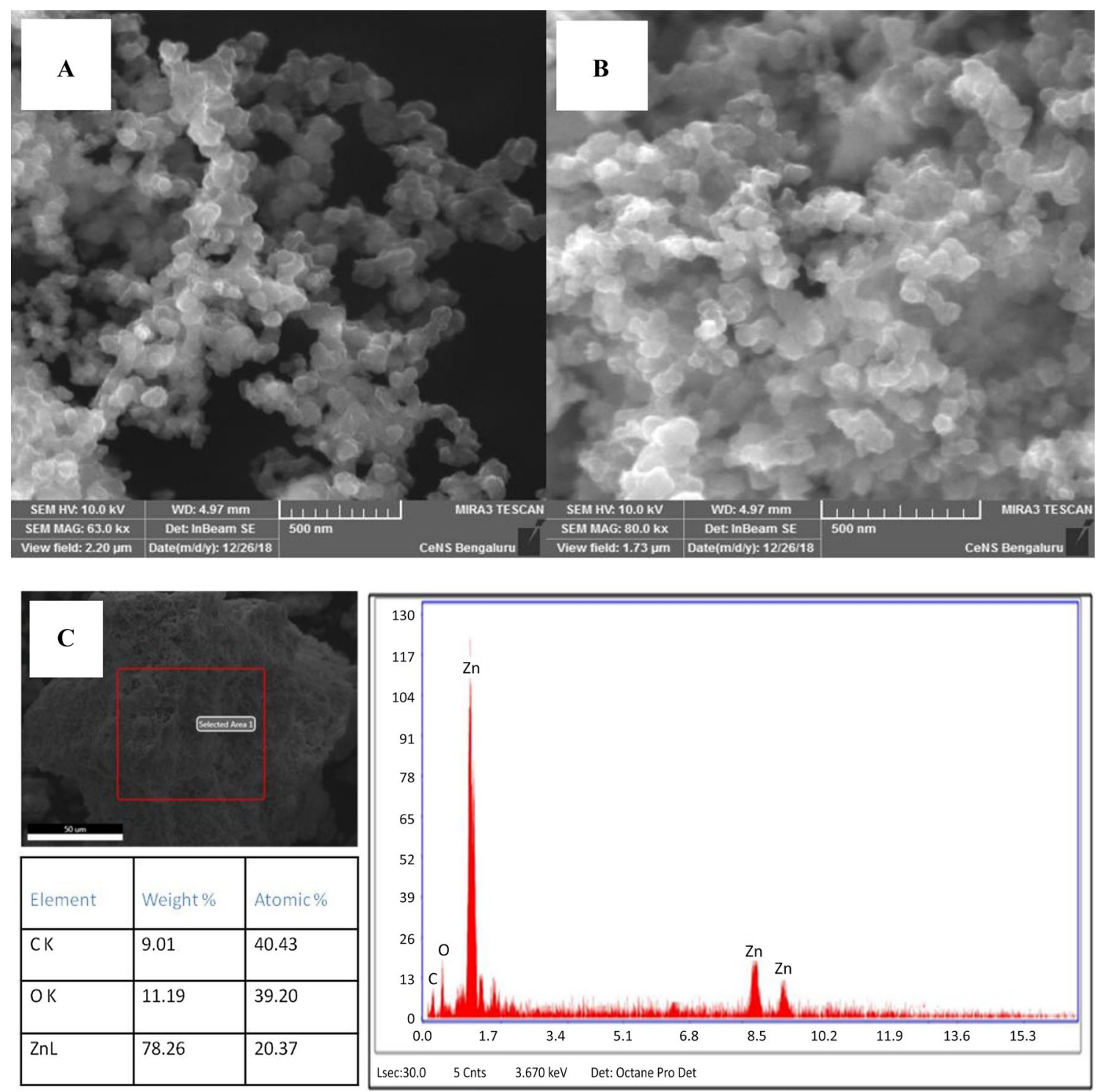

Fig. 3 a Characterization of uncapped ZnO Nps synthesized by the precipitation and microwave method using SEM analysis. b Capped ZnO Nps by the surface modification method using SEM analysis. c EDS spectra of Capped ZnO Nps by the surface modification

Table 1 XRD Data of TiO2 Nanoparticles

\begin{tabular}{llllllllll}
\hline Sample & $2 \theta$ & $\theta$ & $\operatorname{Cos} \theta$ & $\operatorname{Sin} \theta$ & FWHM ( $\left.{ }^{\circ}\right)$ & FWHM radian & $\beta \operatorname{Cos} \theta$ & Size $(\mathrm{nm})$ & $\mathrm{d}$-spacing \\
\hline Uncapped-ZnO & 35.8634 & 17.93 & 0.951 & 0.307 & 0.2732 & 0.004768 & 0.00453 & 30.6 & 2.50 \\
Capped (5\%)-ZnO & 35.8634 & 17.93 & 0.951 & 0.307 & 0.4236 & 0.007393 & 0.00703 & 19.7 & \\
\hline
\end{tabular}

spectra for the $\mathrm{ZnO}$ containing dye as capping agent also showed spectrum of multiple bands, the peaks were shifted in comparison to the pure dye. The band with respect to $\mathrm{O}-\mathrm{H}$ stretching of $-\mathrm{COOH}$ was absent while all other bands appear to be present but slightly shifted towards longer wavelength this shows the covalent bonding of dye with $\mathrm{ZnO}$ nanoparticles as shown in the Fig. 1a. Besides these results the FT-IR spectra of functionalized $\mathrm{ZnO}$ nanoparticle was compared with the previously reported FT-IR spectra of pure $\mathrm{ZnO}$ nanoparticles [35], which appeared to be in good agreement. FT-IR spectrum of ZnO NPs synthesized depends upon 
Fig. 4 Optimised structure of dye calculated by using DFT software quantum espresso

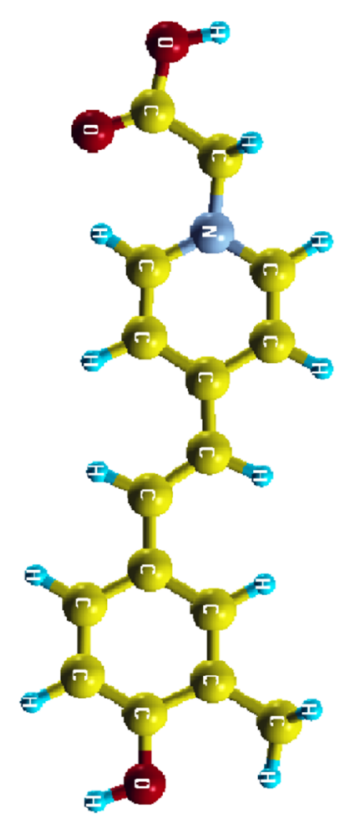

Molecule

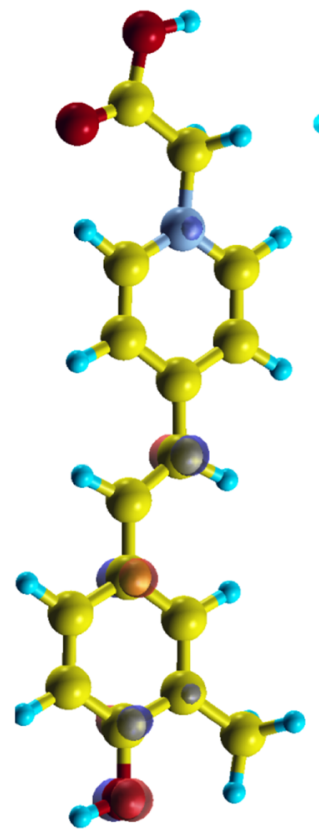

HOMO

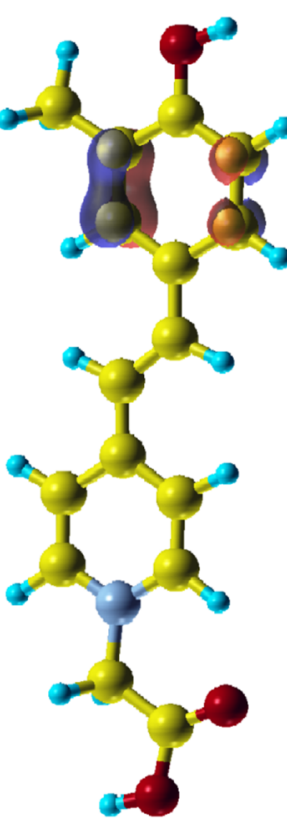

HOMO-1

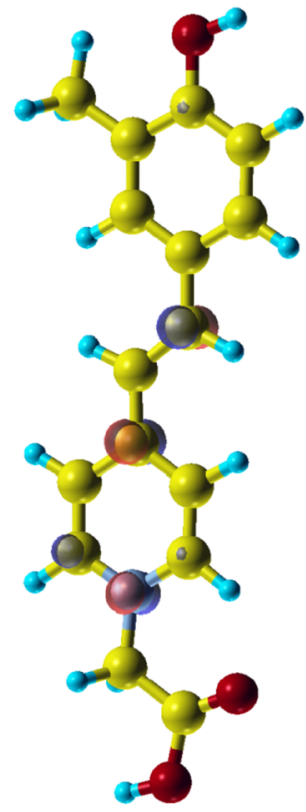

LUMO
Table 2 Zone of inhibition for uncapped $\mathrm{ZnO}$ against E.coli and B.subtilis

\begin{tabular}{|c|c|c|c|c|}
\hline \multirow{3}{*}{$\begin{array}{l}\text { Concentration in } \\
\text { wells }(\mathrm{mg} / \mathrm{ml})\end{array}$} & \multicolumn{4}{|c|}{ Zone of inhibition (mm) } \\
\hline & \multicolumn{2}{|c|}{ Dye uncapped ZnO } & \multicolumn{2}{|c|}{ Dye capped ZnO } \\
\hline & E. coli & B. subtillis & E. coli & B. subtillis \\
\hline 5 & 16 & 19 & 21 & 28 \\
\hline 2.5 & 14 & 17 & 18 & 24 \\
\hline 1.25 & 12 & 15 & 16 & 21 \\
\hline 0.625 & 8 & 11 & 12 & 17 \\
\hline 0.312 & 0 & 7 & 8 & 11 \\
\hline 0.156 & 0 & 0 & 0 & 9 \\
\hline 0.078 & 0 & 0 & 0 & 0 \\
\hline 0.039 & 0 & 0 & 0 & 0 \\
\hline 0.0195 & 0 & 0 & 0 & 0 \\
\hline Control & 0 & 0 & 0 & 0 \\
\hline
\end{tabular}

the type of precursor used in the synthesis of nanoparticle. Strong absorption peaks at $432 \mathrm{~cm}^{-1}$ attributed to $\mathrm{Zn}-\mathrm{O}$ stretching band and the oxygen vacancy in $\mathrm{ZnO}$ at $503 \mathrm{~cm}^{-1}$ was also observed in our case. These discussions are the clear evident that the dye was successfully capped on the surface of the nanoparticles.

From the SEM images of the ZnO NPs (Fig. 3), the morphology was found to be spherical with smooth surface with uniform crystallite and crystallite size structure which is in good agreement with XRD, the effect of capping agent on the surface of nanoparticle can be clearly seen from the images. The XRD patterns of $\mathrm{ZnO}$ samples prepared for capped and uncapped $\mathrm{ZnO}$ are shown in Fig. 2. The peaks at $2 \theta$ values of $31.67^{\circ}, 34.31^{\circ}$, $36.14^{\circ}, 47.40^{\circ}, 56.52^{\circ}, 62.73^{\circ}, 66.28^{\circ}, 67.91^{\circ}, 69.03^{\circ}$, and $72.48^{\circ}$ were assigned to the planes (100), (002), (101), (102), (110), (103), (200), (112) and (201) and are in good agreement with the hexagonal wurtzite structure of $\mathrm{ZnO}$ as confirmed by comparison with the JCPDS card (\#361451). The crystallite size was estimated from the largest peak by using Debye-Scherer formula. The $d$-spacing (inter-planar spacing between atoms) was calculated using Bragg's Law and enumerated in Table 1.

$\mathrm{D}=0.9 \lambda \backslash \beta \operatorname{Cos} \theta$

$2 \mathrm{~d} \sin \theta=\mathrm{n} \lambda$

where $\lambda$ is wave length of X-ray $(0.1540 \mathrm{~nm}), \beta$ is FWHM (full width at half maximum), $\theta$ is diffraction angle, $d$ is $d$-spacing and $D$ is particle diameter size.

\subsection{DFT Calculations}

The structures of dye have been optimized using DFT methods using quantum espresso software. Geometry optimization, molecular energy, Mulliken charges, dipole moments, molecular electrostatic potential calculations were performed. The HOMO and LUMO of the dye is shown below with optimized structure. The K-band for HOMO of dye was found to be 51 (Fig. 4). 
Fig. 5 Plates showing the antibacterial activity of uncapped $\mathrm{ZnO}$ [(a) $5 \mathrm{mg} / \mathrm{ml}]$ and different concentrations of dye capped $\mathrm{ZnO}$ nanoparticles [(b) $1.25 \mathrm{mg} / \mathrm{ml}$, (c) $2.5 \mathrm{mg} / \mathrm{ml}$, (d) $5 \mathrm{mg} / \mathrm{ml}$ ] against. a $E$-Coli, b B. subtilis against
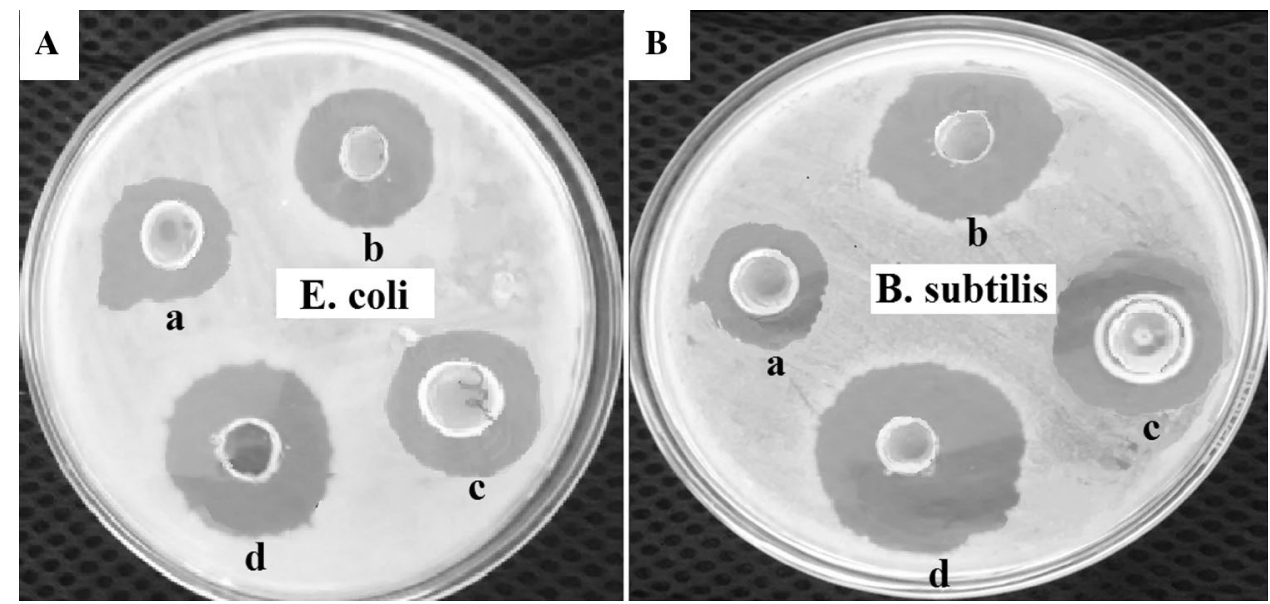

\subsection{Antibacterial activity}

The antimicrobial activity were performed by well diffusion method for both uncapped $\mathrm{ZnO}$ and $3 \%$ dye caped $\mathrm{ZnO}$ nanoparticles on a solid agar plates containing different concentration of nanoparticles, each nanoparticle samples ranging from 0.0975 to $5 \mathrm{mg} / \mathrm{ml}$ were tested against Escherichia coli (ATCC Number 25922) gram negative bacteria and Bacillus Subtillis (ATCC Number 6633) gram positive bacteria. In the present work we have selected $3 \%$ dye capped $\mathrm{ZnO}$ nanoparticles because of their high absorption effiency.

The result of antibacterial studies have been tabulated in Table 2, which shows the deviation in zone of inhibition with respect to change in concentration of capped nanoparticle, from the table it is observed as the nanoparticle concentration increases the of zone of inhibition also increased. The variation in zone of inhibition with respect to change in concentration of nanoparticles and for different bacterial strains is shown in Fig. 4. Zone of inhibition has been shown for E. Coli (Fig. 5a) and B. subtilis (Fig. 5b) for uncapped [(a) $5 \mathrm{mg} / \mathrm{ml}$ ] and different concentrations of dye capped $\mathrm{ZnO}$ nanoparticles [(b) $1.25 \mathrm{mg} / \mathrm{ml}$; (c) $2.5 \mathrm{mg} / \mathrm{ml}$; (d) $5 \mathrm{mg} / \mathrm{ml}$. The result with respect to the minimum inhibitory concentration (MIC) antibacterial studies has been shown in Fig. 6 . The MIC of uncapped $\mathrm{ZnO}$ and capped $\mathrm{ZnO}$ is shown in the Table 3, from the table lower MIC was obtained for B. subtilis for both capped and uncapped nanoparticles but activity was more against capped nanoparticle.

Evaluation of bacterial growth curves in a liquid medium helped us to evaluate the bacteriostatic effect of these nanoparticles, 4 different concentrations $(50,200,500$ and $1000 \mu \mathrm{g} / \mathrm{ml}$ ) were used to study the growth curve of bacteria in solution, significant results were obtained on both strains using uncapped $\mathrm{ZnO}$ and capped $\mathrm{ZnO}$, lower growth was observed in E. coli than B. Subtilis as shown in Fig. 7. The capped $\mathrm{ZnO}$ nanoparticles showed higher antibacterial activity when compared to uncapped nanoparticles, capped

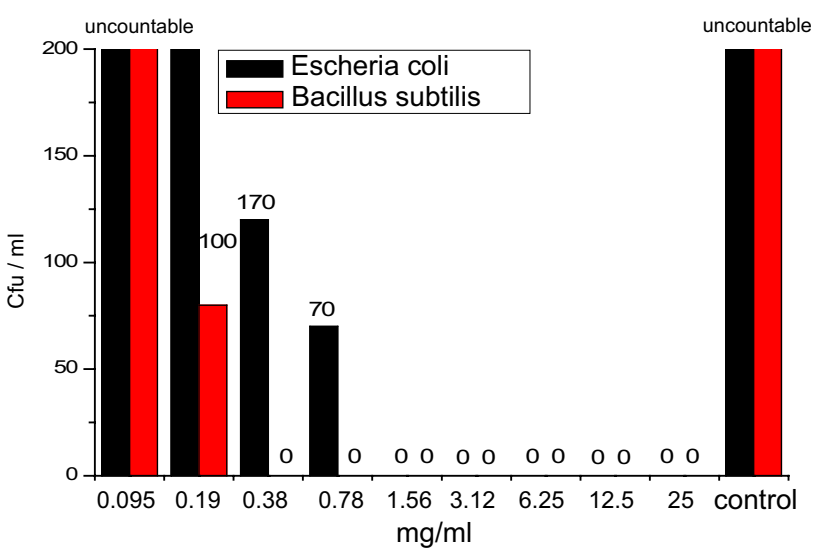

Fig. 6 Number of colony forming units of E. coli and B. subtilis after overnight incubation in the presence of different concentration of dye capped nanoparticle

nanoparticles gave smaller amounts of CFU $/ \mathrm{ml}$ (colony forming unit per $\mathrm{ml}$ ).

In the present work the amount of capping agent used during the synthesis of $\mathrm{ZnO}$ nanoparticles kept constant (3\%), as previous reports suggested that the antibacterial activity varied with quantity of capping agent used, the amount of capping agent influences nanoparticles size. Though in this work we have not studied the effect of different particle size on the antibacterial properties of nanoparticles, instead the effect of functionalization of organic photosensitizer as capping agent on surface of $\mathrm{ZnO}$ nanoparticle which also increases lyophillic nature of nanoparticles was studied. Further the results of the work were compared with previously reported works of Zarrindokht et al. [36] and Mohammed azam et al. [37] it was found that antibacterial activity of synthesised uncapped $\mathrm{ZnO}$ was in good agreement with the reported works. The mechanism of action of $\mathrm{ZnO}$ nanoparticles against bacteria to date is not clear, but however, a few studies 
Table 3 Shows the MIC of the $\mathrm{ZnO}$ and functionalized $\mathrm{ZnO}$ nanoparticles against $B$. Subtilis and $E$. coli

\begin{tabular}{lll}
\hline Bacterial species & \multicolumn{2}{l}{ MIC of the sample $(\mathrm{mg} / \mathrm{ml})$} \\
\cline { 2 - 3 } & Synthesised pure ZnO & $\begin{array}{l}\text { Function- } \\
\text { alized } \\
\mathrm{ZnO}\end{array}$ \\
\hline Bacilus subtilis & 1.56 & 0.38 \\
Escheria coli & 3.12 & 1.56 \\
\hline
\end{tabular}

Fig. 7 Bacterial growth with different concentrations of dye capped ZnO nanoparticles. a Bacillus subtilis ATCC Number 6633, b Escherichia coli ATTC Number 25922 (CFU = colony forming unit) have suggested that the primary cause of the antibacterial function might be binding interaction of the nanoparticles, $\mathrm{ZnO}$ nanoparticles on binding to the outer membrane inhibit active transport and also inhibit RNA, DNA and protein synthesis which leads to death of bacterial cell. Previously reported papers also suggest nanoparticles to react with the thiol group of the proteins in the bacterial cell wall, causing inactivation of transport proteins, reducing cell permeability and causing death of bacteria $[38,39]$ which is the mechanism of present work. Another possibility could be photoinduced antibacterial activity

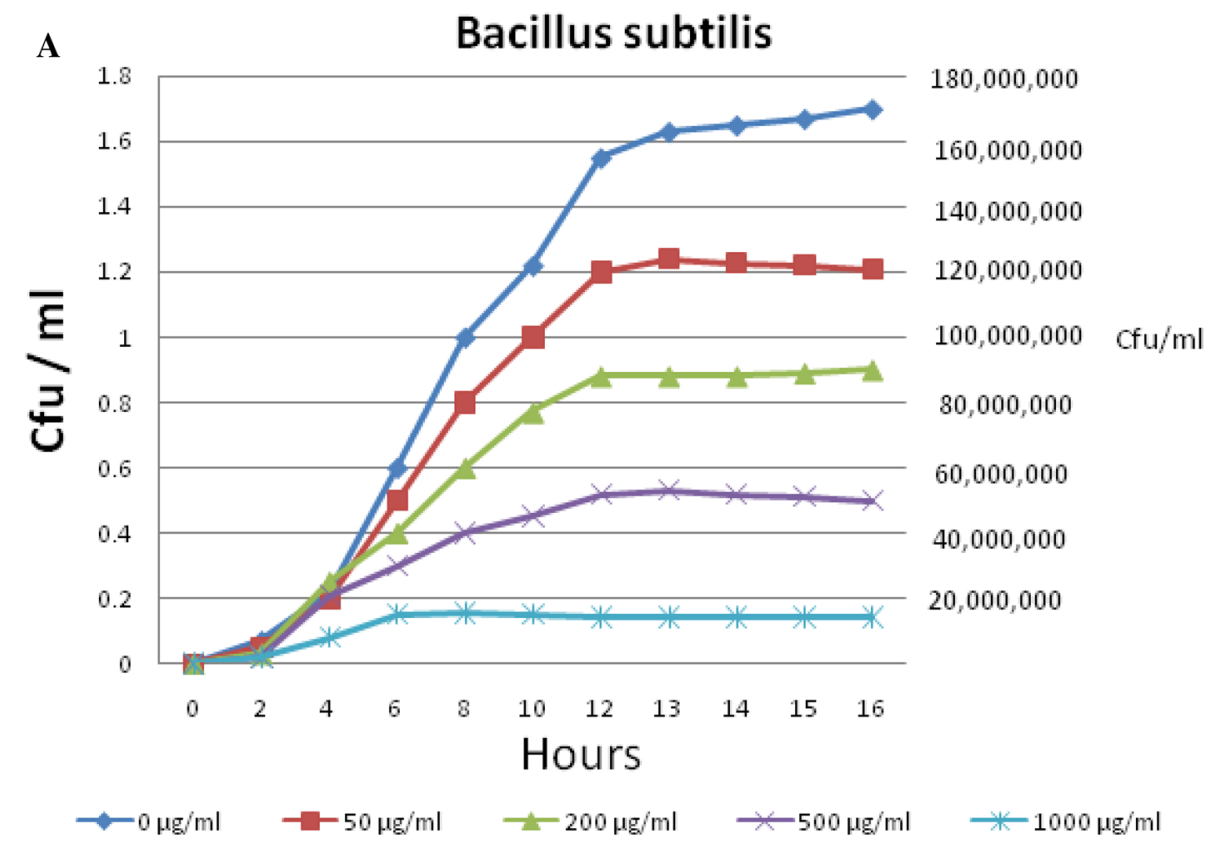

$\mathbf{B}$

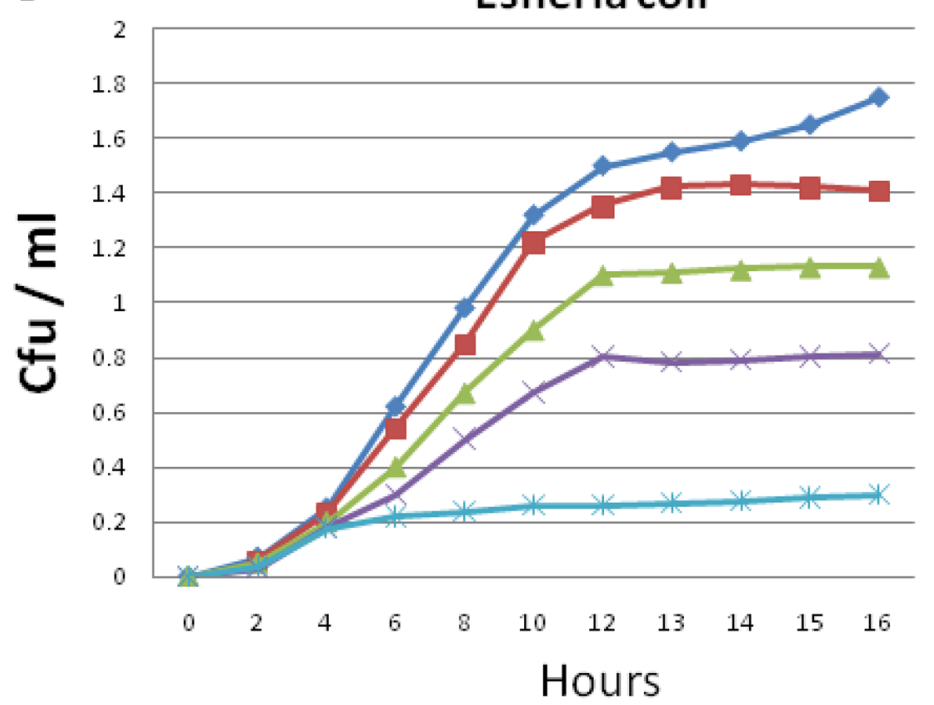

$220,000,000$

$200,000,000$

$180,000,000$

$160,000,000$

$140,000,000$

$120,000,000 \mathrm{Cfu} / \mathrm{ml}$

$100,000,000$

$80,000,000$

$60,000,000$

$40,000,000$

$\multimap 0 \mu \mathrm{g} / \mathrm{ml} \quad-50 \mu \mathrm{g} / \mathrm{ml} \quad \longrightarrow-200 \mu \mathrm{g} / \mathrm{ml} \quad \longleftarrow 500 \mu \mathrm{g} / \mathrm{ml}$

$\approx-1000 \mu \mathrm{g} / \mathrm{ml}$ 
(UV or sunlight) of $\mathrm{ZnO}$ nanoparticles the induction of intercellular reactive oxygen species such as $\mathrm{OH}$ radical, $\mathrm{H}_{2} \mathrm{O}_{2}$, and $\mathrm{O}_{2}{ }^{2-}$. The negatively charged hydroxyl radicals and superoxides cannot penetrate into the cell membrane and are likely to remain on the cell surface, whereas $\mathrm{H}_{2} \mathrm{O}_{2}$ can penetrate into bacterial cells. The reactive oxygen species generated in the process causes oxidative damages to living organism, ROS attack takes place primarily on the cell membrane of bacteria. The damage of cell membrane leads to the leakage of minerals, proteins, and genetic materials which appeared to be the main cause of cell death [40]. The enhanced antibacterial activity of capped nanoparticle is probably attributed to such reasons as, the smaller particle size of capped nanoparticles providing higher surface area to volume ratio, the presence of water soluble organic photosensitizer used in the synthesis of these nanoparticles increases the lyophillic nature of nanoparticles due to functionalization of water soluble organic moieties which leads to easy binding interaction of the nanoparticles to the outer membrane of bacteria.

\section{Conclusion}

The surface modification of $\mathrm{ZnO}$ nanoparticles show increased antimicrobial activity. We witnessed an increase in antimicrobial behaviour of surface dye capped $\mathrm{ZnO}$ nanoparticles compared to the uncapped $\mathrm{ZnO}$ nanoparticles. The synthesized capped $\mathrm{ZnO}$ and uncapped $\mathrm{ZnO}$ nanoparticles, the crystallite sizes were measured to be 19.7 and $30.6 \mathrm{~nm}$ respectively. The effective binding of organic dye on $\mathrm{ZnO}$ nanoparticles is confirmed with FT-IR spectroscopy which showed band at 3400 and $1715 \mathrm{~cm}^{-1}$ in pure dye is attributed to $-\mathrm{COOH}$ stretching, in the capped nanoparticle the peak at $3400 \mathrm{~cm}^{-1}$ is absent and vibration shifted to lower frequency 1625 and $1596 \mathrm{~cm}^{-1}$ in indicating covalent bonding via carboxylic centre to the metal oxide nanoparticle. The main reason for increased antimicrobial effect is due to increase in lyophillic nature of $\mathrm{ZnO} N \mathrm{Ns}$ and decrease in particle size, which increased interaction of ZO NPs with bacterial membrane, intracellular proteins, particularly sulphur-containing membrane proteins and phosphorus-containing DNA. The dye capped nanoparticles exhibit excellent antibacterial effect against $B$. subtilis gram positive bacteria with MIC value of $0.39 \mathrm{mg} / \mathrm{ml}$ and $1.56 \mathrm{mg} / \mathrm{ml}$ against $E$. coli which was much higher than pure $\mathrm{ZnO}$ nanoparticles. Capped $\mathrm{ZnO}$ nanoparticles exhibit excellent antibacterial effect compared to uncapped $\mathrm{ZnO}$ nanoparticles.

Acknowledgements The authors are thankful to the Department of Industrial Chemistry, Kuvempu University, Shankaraghatta, for providing the necessary facilities.

\section{Compliance with ethical standards}

Conflict of interest The authors have no conflict of interest.

\section{References}

1. Priyanka B, Du D, Lin Y (2014) Bioinspired nanoscale materials for biomedical and energy applications. J R Soc Interface 11:20131067

2. Vashist SK, Venkatesh AG, Mitsakakis K, Czilwik G, Roth G, Stetten FV, Zengerle R (2012) Nanotechnology-based biosensors and diagnostics: technology push versus industrial/healthcare requirements. BioNanoSci 2:115-126

3. Mir M, Ishtiaq S, Rabia S, Khatoon M, Zeb A, Khan GM, Rehman A, Din F (2017) Nanotechnology: from in vivo imaging system to controlled drug delivery. Nanoscale Res Lett 12:500

4. Morais MG, Martins VG, Steffens D, Pranke P, Costa JAV (2014) Biological applications of nanobiotechnology. J Nanosci Nanotechnol 14:1007-1017

5. Wang L, Hu C, Shao L (2017) The antimicrobial activity of nanoparticles: present situation and prospects for the future. Int J Nanomed 12:1227-1249

6. Beyth N, Houri-Haddad Y, Domb A, Khan W, Hazan R (2015) Alternative antimicrobial approach: nano-antimicrobial materials evid based complement alternate. Med. 2015:246012

7. Slavin YN, Asnis J, Häfeli UO, Bach H (2017) Metal nanoparticles: understanding the mechanisms behind antibacterial activity. J Nanobiotechnol 15:65

8. Stankic S, Suman S, Haque F, Vidic J (2016) Pure and multi metal oxide nanoparticles: synthesis, antibacterial and cytotoxic properties. J Nanobiotechnol 14:73

9. Srikant V, Clarke DR (1998) On the optical band gap of zinc oxide. J Appl Phys 83:5447-5451

10. Silvero MJC, Rocca DM, Villarmois EA, Fournier $K$, Lanterna $A E$, Pérez MF, Becerra MC, Scaiano JC (2018) Selective photoinduced antibacterial activity of amoxicillin-coated gold nanoparticles: from one-step synthesis to in vivo cytocompatibility. ACS Omega 3:1220-1230

11. Arakha M, Roy J, Sarthi P, Bibekan N, Jha MS (2017) Zinc oxide nanoparticle energy band gap reduction triggers the oxidative stress resulting into autophagy-mediated apoptotic cell death. Free Radic Biol Med 110:42-53

12. Vielkind M, Kampen I, Kwade A (2013) Zinc oxide nanoparticles in bacterial growth medium: optimized dispersion and growth inhibition of pseudomonas putida. Adv Nanopart 2:287

13. Baruah S, Pal SK, Dutta J (2012) Nanostructured Zinc Oxide for Water Treatment. Nanosci Nanotechnol-Asia 2:90-102

14. Smijs TG, Pavel S (2011) Titanium dioxide and zinc oxide nanoparticles in sunscreens: focus on their safety and effectiveness. Nanotechnol Sci Appl 4:95-112

15. Xie Y, He Y, Irwin PL, Jin T, Shi X (2011) Antibacterial activity and mechanism of action of zinc oxide nanoparticles against campylobacter jejuni. Appl Environ Microbiol 77:2325-2331

16. Thangam A, Pritam Ramalakshmi S (2014) Effect Of ZnO nanoparticles against strains of Escherichia coli. Asian J Pharm Clin Res 7:202-206

17. Hsueh Y, Ke W, Hsieh C, Lin K, Tzou D, Chiang C (2015) ZnO nanoparticles affect bacillus subtilis cell growth and biofilm formation. PLoS One 10(6):e0128457

18. Tawfik ZS, Badawi AM, Ahmed HM, Lethy MNE, Abdeen Z (2013) Evaluation of the antimicrobial activity $\mathrm{ZnO} / a m p i c i l l i n$ nanocomposite against sensitive and resistant strains: role of 
$\mathrm{Y}$-irradiation on its biological activity. Int J Green Nanotechnol $4: 240-247$

19. Sabir S, Arshad M, Chaudhari SK, (2014) Zinc oxide nanoparticles for revolutionizing agriculture: synthesis and applications. Sci World J 2014, Article ID 925494

20. Khan I et al (2017) Nanoparticles: properties, applications and toxicities. Arab J Chem 1:1. https://doi.org/10.1016/j.arabj c.2017.05.011

21. Hassan AH (2017) Nanomaterials for alternative antibacterial therapy. Int J Nanomed 12:8211-8225

22. Rifat F, Ravindra R, Pravas RB, Kamrul H, Veena S (2018) Zinc oxide nanoparticles from waste $\mathrm{Zn}-\mathrm{C}$ battery via thermal route: characterization and properties. Nanomaterials 8:717

23. Patil SS, Muhammad AJ, Mostafa AH, Deepak RP, Sang-Wan R (2018) Anchoring MWCNTs to 3D honeycomb ZnO/GaN heterostructures to enhancing photoelectrochemical water oxidation. Appl Surf Sci 463:791-801

24. Junli L, Yuhan W, Jianzhong M, Yi P, Aiqin W (2019) A review on bidirectional analogies between the photocatalysis and antibacterial properties of ZnO. J Alloys Compd 783:898-918

25. Kołodziejczak-Radzimska A, Teofil J (2014) Zinc oxide-from synthesis to application: a review. Materials 7:2813-2881

26. Haq A, Nadhman A, Ullah I, Mustafa G, Yasinzai M, Khan I (2017) Synthesis approaches of zinc oxide nanoparticles: the dilemma of ecotoxicity. 2017, Article ID 8510342

27. Selvakumari D, Subashini P, Rizwana F, Lakshminarayan N (2016) Cost effective methods of Zno nano-powder synthesis. IOSR J Appl Phys 8:51-56

28. Jin J, Shan Y, Yang F, Lai H, Tan H, Liu X, Tang J, Fang Q (2012) Organic photosensitizers with $\mathrm{N}$-carboxymethyl pyridinium acceptor/anchoring group for dye-sensitized solar cells. Synth Met 162:2222-2227

29. Sperandio FF, Huang YY, Hamblin MR (2013) Antimicrobial photodynamic therapy to kill Gram-negative bacteria. Recent Pat Antiinfect Drug Discov 8:108-120

30. Cieplik F, Deng D, Crielaard W, Buchalla W, Hellwig E, Al-Ahmad A, Maisch T (2018) Antimicrobial photodynamic therapy—what we know and what we don't. Crit Rev Microbiol 44:571-589

31. Cai ZB, Bai L, Pan Y, Ma F, Li S, Tian Y (2017) Multipolar symmetric and asymmetric $\mathrm{N}$-heterocyclic compounds with efficient twophoton absorption. J Photochem Photobiol A 346:194-205
32. Jin J, Shan Y, Yang F, Lai H, Tan H, Liu X, Tang J, Fang Q (2012) Organic photosensitizers with $\mathrm{N}$-carboxymethyl pyridinium acceptor/anchoring group for dye-sensitized solar cells. Synth Met 162:2222-2227

33. Kumar GA, Naik HSB, Viswanath R, Suresh GIK, Santhosh KN (2017) Tunable emission property of biotin capped Gd:znS nanoparticles and their antibacterial activity. Mater Sci Semicond Process 58:22-29

34. Bepari RA, Chakrabortty M, Bora SJ, Das BK (2014) Synthesis of $\mathrm{ZnO}$ nanoparticles of variable optical band gap via precursor method. Indian J Chem 53A:1344-1348

35. Samzadeh-Kermani A, Izadpanah F, Mirzaee M (2016) The improvements in the size distribution of zinc oxide nanoparticles by the addition of a plant extract to the synthesis. J Cogent Chem. https://doi.org/10.1080/23312009.2016.1150389

36. Zarrindokht EK, Chehrazi P (2011) Antibacterial activity of ZnO nanoparticle on gram-positive and gram-negative bacteria. Afr J Microb Res 5:1368-1373

37. Ansari MA, Khan HM, Khan AA, Sultan A, Azam A (2012) Synthesis and characterization of the antibacterial potential of ZnO nanoparticles against extended-spectrum $\beta$-lactamasesproducing Escherichia coli and Klebsiella pneumoniae isolated from a tertiary care hospital of North India. Appl Microbiol Biotechnol 94:467-477

38. Joe A, Park SH, Shim KD, Kim DJ, Jhee KH, Lee HW, Heo CH, Kim $H M$, Jang ES (2017) Antibacterial mechanism of $\mathrm{ZnO}$ nanoparticles under dark conditions. J Ind Eng Chem 45:430-439

39. Xie $Y$, He Y, Irwin PL, Jin T, Shi X (2011) Antibacterial activity and mechanism of action of zinc oxide nanoparticles against Campylobacter jejuni. Appl Environ Microbiol 77:2325-2331

40. Li Y, Zhang W, Niu J, Chen Y (2012) Mechanism of photogenerated reactive oxygen species and correlation with the antibacterial properties of engineered metal-oxide nanoparticles. ACS Nano 6:5164-5173

Publisher's Note Springer Nature remains neutral with regard to jurisdictional claims in published maps and institutional affiliations. 